\title{
Magnesium fractionation in different textural groups and commercial crop cultivations of Thai soils
}

\author{
Khabele Z. Ntlopo, Jumpen Onthong, Chakkrit Poonpakdee* \\ Agricultural Innovation and Management Division, Faculty of Natural Resources, Prince of Songkla University, \\ Songkhla 90110 Thailand
}

${ }^{*}$ Corresponding author, e-mail: chakkrit.p@psu.ac.th

Received 16 Jun 2021

Accepted 26 Oct 2021

\begin{abstract}
Thai soils are dominated by extremely weathered and developed Ultisols that are characterized by acidity, low fertility, and high leaching of basic cations, including magnesium ( $\mathrm{Mg}$ ). In this study, the distribution of $\mathrm{Mg}$ chemical fractions in Thai soils and major commercial crop fields was assessed using sequential extraction. Moreover, the status of available soil Mg was estimated using single leaching. Similar distribution patterns of $\mathrm{Mg}$ fractionation in the inorganic soils and the commercial crop cultivation soils were noticed. The mean percentage distributions of $\mathrm{Mg}$ fractions spread in a decreasing magnitude: the mineral $\mathrm{Mg}>$ the available $\mathrm{Mg}>$ the carbonate $\mathrm{Mg}>$ the organic complexed Mg; and the recorded values were 68.43, 22.81, 5.90, and 2.86 in the inorganic soils and 69.67, 23.60, 4.52 , and 2.21 in the commercial crop cultivation soils, respectively. A distinct $\mathrm{Mg}$ fractionation pattern occurred within organic soils with a spread percentage of $71.79,14.68,8.91$, and 4.62 for available $\mathrm{Mg}$, organic complexed $\mathrm{Mg}$, mineral $\mathrm{Mg}$, and carbonate $\mathrm{Mg}$, respectively. The available $\mathrm{Mg}$ concentration within organic soils was $541.21 \mathrm{mg} / \mathrm{kg}$; while the inorganic soils per textural group produced 510.86, 26.87, and $20.89 \mathrm{mg} / \mathrm{kg}$ in fine, medium, and coarse textured soils, respectively. Among the commercial crop cultivation soils, rice and coconut were grown in soils with adequate $\mathrm{Mg}$; whereas oil palm, durian, longkong, and rubber were cultivated in $\mathrm{Mg}$ deficient soils. $\mathrm{Mg}$ is an essential element in plants; therefore, medium, coarse textured soils, and the extremely weathered tropical Ultisols, regardless of their texture, require $\mathrm{Mg}$ replenishment for optimum plant productivity within the tropics.
\end{abstract}

KEYWORDS: magnesium forms, sequential extraction procedure, soil texture, available-Mg

\section{INTRODUCTION}

Tropical soils are mostly acidic and infertile with low values of basic cation plant nutrients, such as magnesium (Mg), calcium (Ca), and potassium (K) [1]. High temperatures and rainfall that are common features in tropical climate result in excessive weathering and development of kaolinitic soils with high contents of aluminum and iron oxides, low $\mathrm{pH}$, and low levels of macro- and micro-nutrients [1]. Thailand is situated in the tropical zone, with estimated annual mean temperature and rainfall around $28^{\circ} \mathrm{C}$ and $1500 \mathrm{~mm}$, respectively [2]. These weather conditions result in extensively weathered soils with high leaching potential. As a result, $40 \%$ of the Thai soils are classified as Ultisols [3] and exhibit poor soil fertility with low organic matter (OM) contents, low levels of basic cations, and kaolinite dominated clay mineralogy $[4,5]$. Hence, the restoration of deteriorating soil fertility in Thailand focuses on mixed chemical fertilizers $\left(\mathrm{N}-\mathrm{P}_{2} \mathrm{O}_{5}-\mathrm{K}_{2} \mathrm{O}\right)$ without addition of $\mathrm{Mg}$ to boost agricultural productivity [6]. As a result, the available $\mathrm{Mg}$ is slowly decreasing, and $\mathrm{Mg}$ deficiency has been recorded in commercial crop production soils $[7,8] . \mathrm{Mg}$ is an essential nutrient for plant growth, playing a vital role in several metabolic processes in the lifecycle of a plant while also serving in adaptive and protective roles in abiotic stress situations [9]. The availability of soil $\mathrm{Mg}$ depends on soil $\mathrm{pH}$, soil texture, and the concentrations of competing cations [10].

Evaluation of soil Mg commonly employs the single extraction, a one-step extraction technique based on bioavailability [11]. The extraction divides bioavailable Mg chemical fractions reflecting the metal forms as water soluble $\mathrm{Mg}$, exchangeable $\mathrm{Mg}$, and mineral $\mathrm{Mg}$ [12]. Ammonium acetate (1 $\mathrm{M} \mathrm{NH}_{4} \mathrm{OAc} \mathrm{pH}$ 7.0) is among the reagents used to extract and estimate available $\mathrm{Mg}$ (Avail-Mg) in the single extraction. Avail$\mathrm{Mg}$ includes both the water soluble $\mathrm{Mg}$ and the exchangeable $\mathrm{Mg}$, the fractions correlated with plant $\mathrm{Mg}$ uptake; and the $1 \mathrm{M} \mathrm{NH}_{4} \mathrm{OAc} \mathrm{pH} 7.0$ gets a general approval because it is easily applied and tends to produce consistent results [13]. However, the single extraction scheme used for $\mathrm{Mg}$ fractionation analysis has limitations, as it gives little information about the soil environmental conditions and their effects on metal fractionation in soil. The sequential extraction process (SEP) can be used to address some of the limitations of the single extraction. The SEP estimates metal fractions in soil with the general purpose of selective extraction to simulate the release of the distinct metal forms into a solution under various environmental conditions [14]. It begins from the weakly bound fraction to the strongest crystalline structure, and using a range of reagents from the least hostile extractant to the most aggressive reagent [14]. Additional benefits of the SEP include clear outcome about the existence of distinct chemical forms of an element from the 
use of several reagents. The existence of each fraction, weather as bioavailable, acid-soluble, mineral, oxidizable or reducible forms, can be related to soil environmental conditions through the help of the SEP protocol $[11,15]$. Moreover, prior to any remediation to replenish $\mathrm{Mg}$ in soil, the SEP can provide additional understanding of solubility, availability, and precipitation of $\mathrm{Mg}$; and this information can enable reliable evaluation of the metal elements in soil [12]. Although the SEP was originally developed for the assessment of trace elements, the approach has already been accepted successful in evaluating other elements linked to soil fertility, such as P [16], $\mathrm{Ca}$ [17], K [11], and $\mathrm{Mg}$ $[18,19]$. The fractionation of $\mathrm{Mg}$ in soil reveals different levels of $\mathrm{Mg}$ reserves in various forms of existence and, therefore, signifies the potential bioavailability of $\mathrm{Mg}$ in soil. The SEP allocates Mg into four forms as follows. (1) The available $\mathrm{Mg}$ (Avail-Mg), a fraction combining the water-soluble $\mathrm{Mg}$ ( $\mathrm{Mg}$ in soil solution) and the exchangeable $\mathrm{Mg}$ that is a fraction weakly held within clay and humus particles but still in contact with soil solution and readily replaceable, and plants take up $\mathrm{Mg}$ in this form [18,19]. (2) The organic complexed $\mathrm{Mg}$ (OM-Mg) is formed while the soluble $\mathrm{Mg}$ combines with organic ligands in the rhizosphere resulting in a slowly bioavailable $\mathrm{Mg}$ in a complexed form $[18,19]$. (3) The carbonate/acid soluble $\mathrm{Mg}$ (Acid-Mg) is the fraction that is related to carbonate minerals; dolomite and magnesite are common $\mathrm{Mg}$ carbonates [19]. (4) The last fraction is the mineral $\mathrm{Mg}$ (Mineral-Mg), the fraction fixed in the crystalline soil minerals [19].

Information about the distribution of $\mathrm{Mg}$ chemical fractions in organic and inorganic Thai soils and their relationships with soil properties is very scarce. Therefore, an evaluation of $\mathrm{Mg}$ chemical fractions in organic soils and different textural groups of inorganic soils was essential. The resulting information can be used as a reference regarding the soil $\mathrm{Mg}$ reserves and quantities of different $\mathrm{Mg}$ forms in soil, and subsequently facilitate proper $\mathrm{Mg}$ fertilizer management for precision of agricultural practices. This study was carried out as an initial wide-ranging effort aimed to investigate the distribution of $\mathrm{Mg}$ fractionation in different textural groups of Thai inorganic soils, organic soils, and commercial crop cultivation soils.

\section{MATERIALS AND METHODS}

\section{Sampling and sample preparation}

Thai soils with varying physicochemical properties from various Thai soil orders were collected from the depth of $0-30 \mathrm{~cm}$ and grouped as inorganic soils (all soils except the suborder Histels and order Histosols) and organic soils that are characterized by Soil Taxonomy [24]. The inorganic soils were further subdivided into textural groups as fine, medium, and coarse textured soils. The fine textured soil group $(n=10)$ included the soil series of Pak Chong:Pc, Ao Luek:Ak, Lop Buri:Lb, Hat Yai:Hy, Ruso:Ro, Klaeng:Kl, Bangkok:Bk, Takhli:Tk, Munoh:Mu, Tha Chin:Tc, and Lam Narai:Ln. The medium textured soil group $(n=6)$ included Phuket:Pk, Fang Daeng:Fd, Sawi:Sw, Visai:Vi, and Nam Kracha:Ni. Lastly, the coarse textured soil group ( $\mathrm{n}=5)$ comprised Kho Hong:Kh, Khok Khain:Ko, Tha Sae:Te, Thung Wa:Tg, and Bacho:Bc. Organic soils $(n=2)$ from Daeng:Kd and Narathiwat:Nw were also covered in this study (Table S1). Additional 30 soil samples, five each from 6 major commercial crop fields in Thailand representing rubber, coconut, oil palm, longkong, durian, and rice, were also used. The soil samples were air-dried, ground, and passed through a 2-mm sieve for determining soil basic properties, with a further subsample passed through a $0.50 \mathrm{~mm}$ sieve for $\mathrm{Mg}$ fractionation analysis and organic matter content.

\section{The physicochemical properties analysis}

The physicochemical properties of the soil samples were determined following standard methods [13]. Soil $\mathrm{pH}$ and electrical conductivity (EC) were measured in the supernatant of 1:5 (w/v soil:deionized water). Organic matter was determined using Walkley and Black method. The Bray II procedure was applied to establish the available phosphorus (Avail. P). Total nitrogen was evaluated by Kjeldahl method. A $1 \mathrm{M}$ $\mathrm{NH}_{4} \mathrm{OAc}$ solution $\mathrm{pH} 7.0$ was used to saturate the exchange sites for the estimation of cation exchange capacity (CEC), the supernatant was used to estimate extractable $\mathrm{K}, \mathrm{Ca}$, and $\mathrm{Mg}$ (Extr. $\mathrm{K}, \mathrm{Ca}$, and $\mathrm{Mg}$ ), and the soil texture was assessed following the pipette method [20].

\section{Magnesium speciation analysis}

The SEP was used to determine $\mathrm{Mg}$ chemical fractions, and each sample was replicated 3 times. A 1.00gram (g) soil sample was subjected to an uninterrupted four step sequence of extractions for Avail$\mathrm{Mg}$, OM-Mg, Acid-Mg, and Mineral-Mg with the respective extractants and conditions (Table 1). Each suspension was centrifuged at relative centrifugal force (RCF) of $1588 \mathrm{~g}$ and the supernatant was decanted and passed through a Whatman No. 5 filter paper into polythene plastic bottles. The sample was double washed with deionized water and solutions were discarded prior to the next reagent use. Finally, the residue from preceding extraction was transferred into a $50 \mathrm{ml}$ beaker where it was oven dried for $24 \mathrm{~h}$. The dried sample was digested with $25 \mathrm{ml}$ tri-acid mixture $\left(\mathrm{HNO}_{3}: \mathrm{HClO}_{4}: \mathrm{H}_{3} \mathrm{PO}_{4}\right)$ at the percentage ratio of $23: 54: 23 \mathrm{v} / \mathrm{v}$ on a hotplate at $150{ }^{\circ} \mathrm{C}$ until soil particles changed to white.

All the supernatants were analyzed for $\mathrm{Mg}$ fraction concentrations by Atomic Absorption Spectrophotometer (AAS; iCE 3000 series, Thermo Scientific, USA). For 
Table 1 Sequential extraction procedure for $\mathrm{Mg}$ fractionation [19].

\begin{tabular}{|c|c|c|c|c|c|c|}
\hline Step & Form/association & Extraction reagent & Activity & $\begin{array}{l}\text { Time } \\
(\min )\end{array}$ & $\begin{array}{l}\text { Temp } \\
\left({ }^{\circ} \mathrm{C}\right)\end{array}$ & $\begin{array}{l}\text { Final volume } \\
\quad(\mathrm{ml})\end{array}$ \\
\hline 1 & Available Mg & $25 \mathrm{ml}$ of $1 \mathrm{M} \mathrm{NH}_{4} \mathrm{OAc} \mathrm{pH} 7.0$ & Shaking & 60 & 25 & 25 \\
\hline 2 & Organic complexed $\mathrm{Mg}$ & $10 \mathrm{ml}$ of $10 \% \mathrm{H}_{2} \stackrel{4}{\mathrm{O}}_{2}$ & Shaking & 120 & 25 & 10 \\
\hline 3 & Acid-soluble $\mathrm{Mg}$ & $\begin{array}{l}30 \mathrm{ml} \text { of } 1 \mathrm{M} \mathrm{HNO}_{3} \text {, adjust with } 0.2 \mathrm{M} \\
\mathrm{HNO}_{3} \text { to } 50 \mathrm{ml}\end{array}$ & Boiling & 15 & 85 & 50 \\
\hline 4 & Mineral Mg & $\begin{array}{l}25 \mathrm{ml} \text { of triacid mixture, } 5 \mathrm{ml} \text { of } \\
5 \mathrm{M} \mathrm{HCl} \text { after decanting and adjust to } \\
25 \mathrm{ml} \text { with DI water. }\end{array}$ & Heating & $90-120$ & 150 & 25 \\
\hline
\end{tabular}

\footnotetext{
" Tri-acid mixture $=\mathrm{HNO}_{3}+\mathrm{HClO}_{4}+\mathrm{HPO}_{4}$ at $23 \%: 54 \%: 23 \% \mathrm{v} / \mathrm{v}$.
}

quality and accuracy control, a single digestion step for total-Mg was carried out and used to calculate the percentage of Mg recovery

$$
\operatorname{Mg} \text { recovery }(\%)=\frac{\sum_{n} \mathrm{Mg} \text { fractions }(\text { pseudo }- \text { total-Mg })}{\text { total-Mg }} \times 100
$$

where $\sum_{n}$ is the sum concentration of $\mathrm{Mg}$ species from individual steps for (pseudo-total-Mg), and total-Mg was a single tri-acid mixture digestion soil $\mathrm{Mg}$ concentration value [11]. In this study $\mathrm{Mg}$ concentration recovery based on SEP analysis was accepted within $15 \%$ error.

Percentage was used for the separation of $\mathrm{Mg}$ distributions in different soil types, between textural groups and commercial crops. Pearson correlation analysis at $5 \%$ and $1 \%$ significance level was used to assess the interrelations between $\mathrm{Mg}$ species and the different soil properties.

\section{RESULTS}

\section{Soil physicochemical properties}

Inorganic and organic soils showed soil $\mathrm{pH}$ ranging from strongly acidic (3.66) to slightly alkaline (8.05) (Table 2 and Table 3). Maximum CEC in the inorganic and the organic soils were 54.25 and $104.75 \mathrm{cmol}_{\mathrm{c}} / \mathrm{kg}$, respectively. The OM percentages in some inorganic soils were higher than normal with the ranges of 9.95$56.92 \mathrm{~g} / \mathrm{kg}$ for fine, $8.50-11.98 \mathrm{~g} / \mathrm{kg}$ for medium, and 6.01-13.37 g/kg for coarse textured soils. However, OM content was smaller in the inorganic soils (6.01$56.95 \mathrm{~g} / \mathrm{kg}$ ) than in the organic soils $(432-448 \mathrm{~g} / \mathrm{kg})$ as expected.

\section{Distribution of Mg chemical fractions in soils}

The mean total $\mathrm{Mg}$ concentrations in organic and inorganic soils were 606.10 and $707.83 \mathrm{mg} / \mathrm{kg}$, respectively (Table S3). In the inorganic soils, the percentages of Avail-Mg were in a descending range of $40.45,16.02$, and $11.96 \%$ for fine, medium, and coarse textured soils, respectively (Fig. 1a). The mineral-Mg fractions in medium, coarse, and fine soils were calculated at $82.35,76.12$, and $46.81 \%$, respectively. The $\mathrm{OM}-\mathrm{Mg}$ generated an average value of just $2 \%$ in the

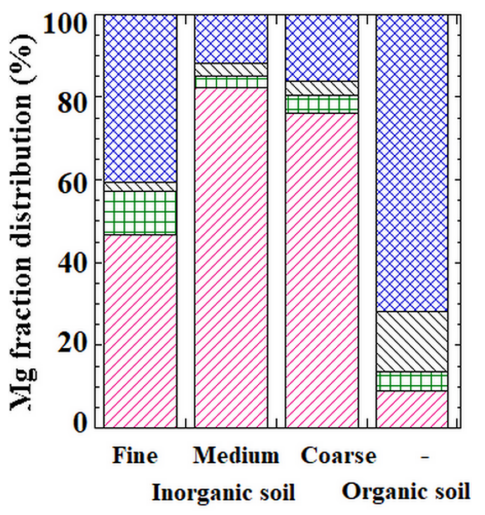

(a)

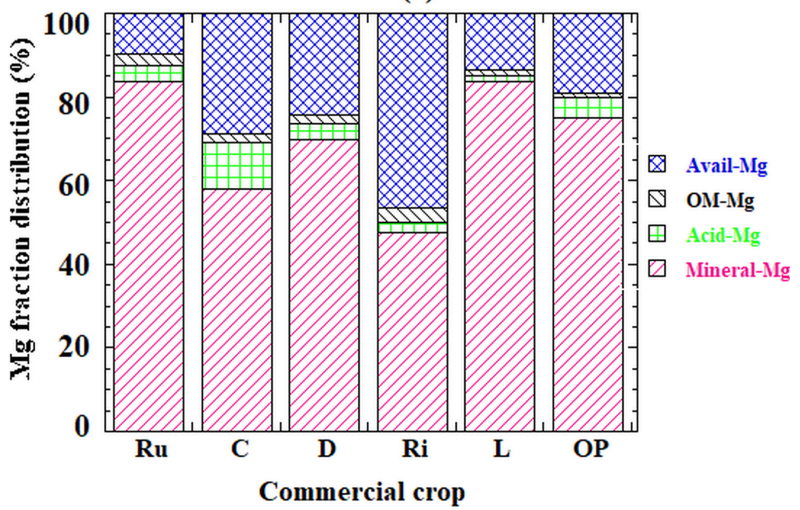

(b)

Fig. $1 \mathrm{Mg}$ chemical fractions in Thai soil series (a) and commercial crop cultivation soils (b). Note: $\mathrm{Ru}=$ rubber, $\mathrm{C}$ = coconut, $\mathrm{D}=$ durian, $\mathrm{Ri}=$ rice, $\mathrm{L}=$ longkong, $\mathrm{OP}=$ oil palm.

inorganic soils. The Acid-Mg was distributed within $10.60 \%$ of the total $\mathrm{Mg}$ distribution in fine textured soils and an average of $5 \%$ in both the medium and the coarse textured soils. In the organic soils, the percentages of $\mathrm{Mg}$ fraction were in descending order of Avail-Mg $>\mathrm{OM}-\mathrm{Mg}>$ Mineral-Mg $>$ Acid-Mg at 71.79, $14.68,8.91$ and $4.62 \%$, respectively. In this study, the commercial crop cultivation soils properties (Table 3) 
Table 2 The physicochemical properties of inorganic and organic Thai soils.

\begin{tabular}{|c|c|c|c|c|c|c|c|c|}
\hline \multirow{3}{*}{ Soil property } & \multicolumn{6}{|c|}{ Inorganic soil $(n=21)$} & \multicolumn{2}{|c|}{ Organic soil $(n=2)$} \\
\hline & \multicolumn{2}{|c|}{ Fine textured $(n=10)$} & \multicolumn{2}{|c|}{ Medium textured $(n=6)$} & \multicolumn{2}{|c|}{ Coarse textured $(n=5)$} & \multicolumn{2}{|l|}{ - } \\
\hline & Range & Mean & Range & Mean & Range & Mean & Range & Mean \\
\hline pH (1:5 soil:water) & $3.66-8.05$ & 6.24 & $4.34-5.35$ & 4.84 & $5.07-5.37$ & 5.21 & $3.78-4.01$ & 3.89 \\
\hline $\mathrm{EC}(\mathrm{dS} / \mathrm{m})$ & $0.02-8.67$ & 1.00 & $0.02-0.07$ & 0.04 & $0.01-0.03$ & 0.02 & $0.12-0.12$ & 0.12 \\
\hline $\mathrm{OM}(\mathrm{g} / \mathrm{kg})$ & 9.95-56.92 & 22.63 & $8.50-11.98$ & 10.36 & $6.01-13.37$ & 10.96 & $432.0-448.1$ & 440.00 \\
\hline Total N (g/kg) & $0.51-1.90$ & 1.09 & $0.34-0.78$ & 0.57 & $0.37-0.71$ & 0.53 & $8.01-9.38$ & 8.69 \\
\hline Avail. P (mg/kg) & 3.02-31.04 & 13.01 & $3.89-9.88$ & 7.50 & $4.30-17.52$ & 7.97 & $5.72-11.06$ & 8.39 \\
\hline $\mathrm{CEC}\left(\mathrm{cmol}_{\mathrm{c}} / \mathrm{kg}\right)$ & $1.40-54.25$ & 20.53 & $1.20-4.43$ & 3.01 & $1.11-4.36$ & 2.54 & 85.39-104.75 & 95.07 \\
\hline Extr. ${ }^{*}(\mathrm{mg} / \mathrm{kg})$ & $15.68-876.63$ & 135.63 & $7.21-52.75$ & 20.43 & 4.89-15.15 & 10.03 & $19.85-321.30$ & 170.57 \\
\hline Extr. Ca* $(\mathrm{mg} / \mathrm{kg})$ & $12.4-13149.5$ & 5367.31 & $18.56-62.18$ & 74.19 & $21.92-112.98$ & 42.00 & $602.39-877.63$ & 740.01 \\
\hline
\end{tabular}

Range shows minimum and maximum values, "extracted using $1 \mathrm{M} \mathrm{NH}_{4} \mathrm{OAc} \mathrm{pH}$ 7.0.

Table 3 Basic physicochemical properties of commercial crop cultivation soils.

\begin{tabular}{lcccccccccccc}
\hline Crop & $\begin{array}{c}\mathrm{pH} \\
(1: 5)\end{array}$ & $\begin{array}{c}\mathrm{EC} \\
(\mathrm{dS} / \mathrm{m})\end{array}$ & $\begin{array}{c}\text { Total N } \\
(\mathrm{g} / \mathrm{kg})\end{array}$ & $\begin{array}{c}\mathrm{OM} \\
(\mathrm{g} / \mathrm{kg})\end{array}$ & $\begin{array}{c}\text { Avail. P } \\
(\mathrm{mg} / \mathrm{kg})\end{array}$ & $\begin{array}{c}\text { Extr. Ca } \\
(\mathrm{mg} / \mathrm{kg})\end{array}$ & $\begin{array}{c}\text { Extr. K } \\
(\mathrm{mg} / \mathrm{kg})\end{array}$ & $\begin{array}{c}\text { Sand } \\
(\%)\end{array}$ & $\begin{array}{c}\text { Clay } \\
(\%)\end{array}$ & $\begin{array}{c}\text { Silt } \\
(\%)\end{array}$ & $\begin{array}{c}\text { Textural } \\
\text { class }\end{array}$ & $\begin{array}{c}\text { Textural } \\
\text { group }\end{array}$ \\
\hline Rubber $(\mathrm{n}=5)$ & 5.3 & 0.02 & 0.82 & 16.96 & 26.1 & 75.5 & 29.8 & 46 & 28 & 28 & SCL & Coarse \\
Coconut (n=5) & 6.8 & 0.04 & 1.00 & 20.95 & 13.0 & 1820.4 & 95.8 & 59 & 26 & 15 & SCL & Coarse \\
Durian (n=5) & 5.0 & 0.04 & 0.62 & 14.97 & 28.6 & 123.8 & 93.0 & 62 & 17 & 21 & SL & Coarse \\
Rice (n=5) & 4.8 & 0.25 & 0.66 & 16.92 & 13.2 & 565.6 & 158.6 & 5 & 38 & 57 & SiC & Fine \\
Longkong (n=5) & 4.7 & 0.04 & 1.01 & 21.95 & 24.2 & 150.3 & 62.7 & 55 & 32 & 13 & SCL & Coarse \\
Oil palm (n=5) & 4.1 & 0.19 & 1.32 & 27.94 & 4.0 & 187.6 & 31.5 & 39 & 28 & 34 & L & Medium \\
\hline
\end{tabular}

$\mathrm{SCL}=$ sandy clay loam, $\mathrm{SL}=$ sandy loam, $\mathrm{SiC}=$ silty clay, $\mathrm{L}=$ loam.

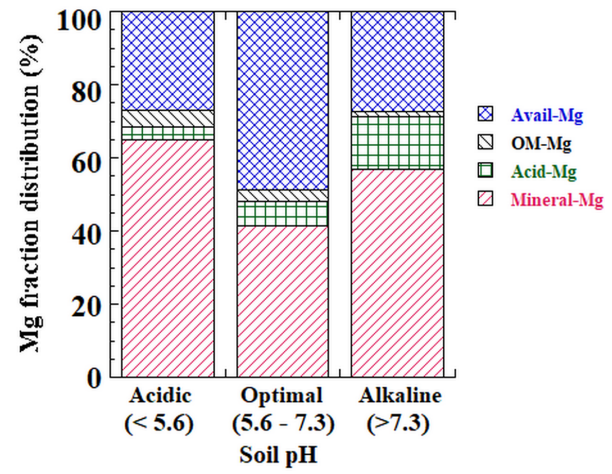

Fig. $2 \mathrm{Mg}$ chemical fractions in Thai soils series based on soil $\mathrm{pH}$.

categorized them within mineral soils as classified by Soil Taxonomy [24]. The joint order and magnitude of $\mathrm{Mg}$ fractionation results closely matched those from Thai soil series characterized through soil taxonomy, the Mineral-Mg range (47.66-88.77\%) covered the largest percentage of the fractionation distribution, followed by Avail-Mg (5.48-46.33\%), Acid-Mg (1.52$8.65 \%)$ and OM-Mg (1.52-4.19\%) (Fig. 1b). The percentage of Avail-Mg was highest in rice growing soils at 46.33 followed by coconut growing soils with 30.42 . Lastly, OM-Mg in all soils was below 5\% while Acid-Mg was highest in coconut growing soils at $8.67 \%$.

$\mathrm{Mg}$ speciation based on soil pH category (Fig. 2) indicated that the Avail-Mg dominated in optimal soil
$\mathrm{pH}$ (48.90\%), while both acidic and alkaline soils yielded around $27 \%$ of the Avail-Mg. The Acid-Mg increased with soil $\mathrm{pH}$ as depicted by percentages of $3.71,6.51$, and 14.39 in acidic, optimal, and alkaline soil $\mathrm{pH}$, respectively.

\section{Available Mg status in soils}

The Avail-Mg concentrations from $1 \mathrm{M} \mathrm{NH} \mathrm{NH}_{4} \mathrm{OAc}$ $\mathrm{pH} 7.0$ extraction were high in the fine textured soils $(510.86 \mathrm{mg} / \mathrm{kg}$ ) and the organic soils $(541.21 \mathrm{mg} / \mathrm{kg})$, while lower concentrations were observed in the medium (26.86 $\mathrm{mg} / \mathrm{kg}$ ) and the coarse textured (20.89 mg/kg) soils, (Fig. 3a). Longkong, oil palm, rubber, and durian growing soils produced low contents of Avail-Mg ranging within 20.13-60.90 mg/kg and revealed low concentration relative to the $\mathrm{Mg}$ optimal level (Fig. 3b). In the contrary, high Avail-Mg was found in rice growing soils $(466.53 \mathrm{mg} / \mathrm{kg}$ ), while coconut growing soils produced moderate concentration $(173.64 \mathrm{mg} / \mathrm{kg}$ ) of Avail-Mg.

\section{The correlations between the soil $\mathrm{Mg}$ fractionation and the soil properties}

Significant correlations within the fractionation of $\mathrm{Mg}$ (Table 4) and the several soil properties (Table 5) were observed. The Avail-Mg correlated strongly with clay particles $(r=0.723 * *)$. OM-Mg displayed moderate positive correlation with OM $(r=0.620 * *)$ and total $\mathrm{N}\left(r=0.643^{* *}\right)$; and strong correlation with CEC $(r$ $=0.808 * *)$. The Acid-Mg had significant correlation with soil $\mathrm{pH}\left(r=0.760^{* *}\right)$. The majority of $\mathrm{Mg}$ 


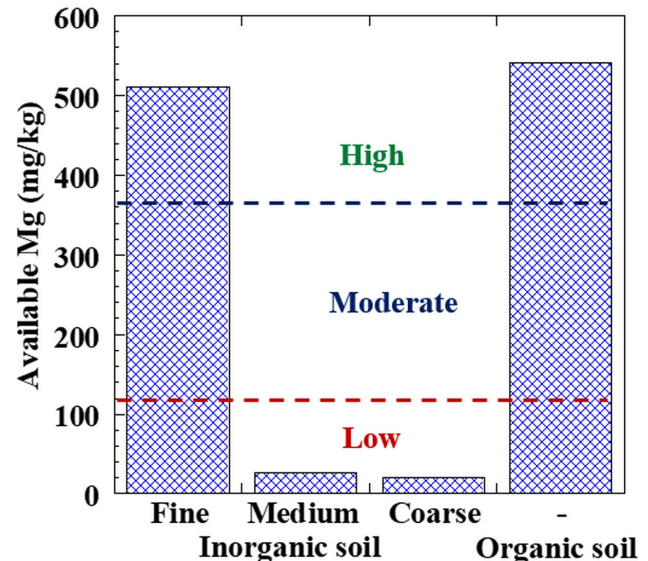

(a)

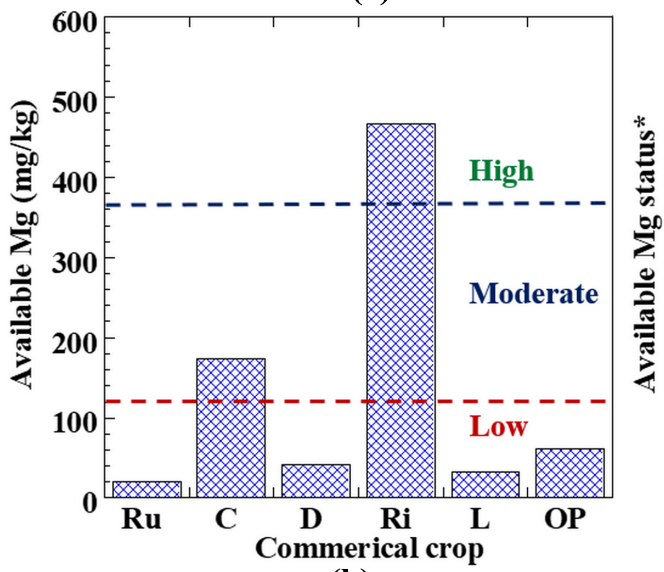

(b)

Fig. 3 Available $\mathrm{Mg}$ status in Thai soil series (a) and in commercial crop cultivation soils (b). Note: $\mathrm{Ru}=$ rubber, $\mathrm{C}$ $=$ coconut, $\mathrm{D}=$ durian, $\mathrm{Ri}=$ rice, $\mathrm{L}=$ longkong, $\mathrm{OP}=$ oil palm. * Available Mg status (low < $122 \mathrm{mg} / \mathrm{kg}$, moderate $122-365 \mathrm{mg} / \mathrm{kg}$, high $>365 \mathrm{mg} / \mathrm{kg}$ ) based on Department of Land Development [21].

Table 4 The correlation coefficients ( $r$ ) in $\mathrm{Mg}$ fractionation in Thai soils.

\begin{tabular}{lllll}
\hline Mg speciation & Avail-Mg & OM-Mg & Acid-Mg & Mineral-Mg \\
\hline OM-Mg & $0.660^{* *}$ & & & \\
Acid-Mg & $0.537^{* *}$ & $0.486^{*}$ & & \\
Mineral-Mg & 0.397 & 0.111 & $0.805^{* *}$ & \\
Total-Mg & $0.742^{* *}$ & $0.468^{*}$ & $0.893^{* *}$ & $0.805^{* *}$ \\
\hline
\end{tabular}

$*, * *$ Correlation is significant at $p \leqslant 0.05$ or 0.01 , respectively.

forms generated positive significant correlations with clay particles and negative significant correlations with sand particles (Table 5).

\section{DISCUSSION}

\section{Soil physicochemical properties}

Soil $\mathrm{pH}$ range stayed within the acidic status in organic and inorganic soils (Table 2), and this indicated the prevalence of acidity within Thai soils. These results align with a general view that the majority of tropical soils are acidic in nature [22]. The contents of OM, total N, available P, and CEC were low in inorganic soils. Similarly, commercial cultivation fields displayed parallel physicochemical properties, except for the coconut growing soils that demonstrated higher soil $\mathrm{pH}$ (close to neutral) at pH 6.84 (Table 3). Similar results have been reported for rubber growing soils that were acidic with low salinity and OM content, and infertile with low values of CEC [23]. Thai commercial crops are grown in coarse textured soils, excluding oil palm and rice, which are both farmed in medium and fine textured soils. The Ln and Tk soils with average CEC of over $40 \mathrm{cmol}_{\mathrm{c}} / \mathrm{kg}$ and $\mathrm{pH}$ above 8.0 were Mollisols displaying surface soil characteristics of high base cation saturation. Mollisols have a base saturation of over $50 \%$ in the epipedon [24]; hence, they also revealed a high $\mathrm{Mg}$ content. The Lb soil represents Vertisols with high soil $\mathrm{pH}(7.26)$ and CEC (54.25 $\left.\mathrm{cmol}_{\mathrm{c}} / \mathrm{kg}\right)$ (Table S1 and Table S2). The Tc soil exhibited high salinity $(8.66 \mathrm{dS} / \mathrm{m})$ and $\mathrm{Ca}(8572 \mathrm{mg} / \mathrm{kg})$ represents Entisols (Table S1 and Table S2). Tc soil series is formed from marine sediments practically waterlogged with sea-water and has an alkaline $\mathrm{pH}$ and high salinity [3,25]. The Organic soils (Histosols) produced comparatively high OM $(440 \mathrm{~g} / \mathrm{kg})$ and CEC (95.07 $\mathrm{cmol}_{\mathrm{c}} / \mathrm{kg}$ ), consistent with the classification of organic soils, and the Thai organic soils' OM content assigns them to peat soils with OM above $300 \mathrm{~g} / \mathrm{kg}$ [26].

In the inorganic soils, the $\mathrm{Mg}$ chemical fraction distribution of the Mineral-Mg, Avail-Mg, Acid-Mg, and OM-Mg were $46.81,40.44,10.60$, and $2.15 \%$ in the fine textured soils; $82.35,11.96,2.61$, and $3.08 \%$ in the medium textured soils; and 76.12, 16.02, 4.51, and $3.35 \%$ in the coarse textured soils; respectively. In summary, the observed $\mathrm{Mg}$ fractionation rank order was Mineral-Mg $>$ Avail-Mg $>$ Acid-Mg $>\mathrm{OM}-\mathrm{Mg}$, estimated collectively at $68.43,22.81,5.90$, and $2.86 \%$, respectively. These results slightly differ from the order of previous studies, Mineral-Mg $>$ Acid-Mg $>$ Avail-Mg $>\mathrm{OM}-\mathrm{Mg}$ [18]. In contrast, the organic soils produced an altered order of the $\mathrm{Mg}$ fractionation ranks as Avail$\mathrm{Mg}>\mathrm{OM}-\mathrm{Mg}>$ Mineral-Mg $>$ Acid-Mg with the fractionation distribution of $71.79,14.68,8.91$, and $4.62 \%$, respectively. Organic soils develop from the decomposition of plant litters; and, therefore, the presence of different binding sites in the soil leads to the formation of various Mg-organic complexes, resulting in increased OM-Mg (Fig. 1a). Soluble metal organic complexes accelerate metal diffusion in soils [27]. The elevated OM-Mg in organic soils was established as the 
Table 5 The correlation coefficients $(r)$ between the Mg fractionation and the soil properties.

\begin{tabular}{|c|c|c|c|c|c|}
\hline Soil property & Avail-Mg & $\mathrm{OM}-\mathrm{Mg}$ & Acid-Mg & Mineral-Mg & Total-Mg \\
\hline $\mathrm{pH}$ & 0.234 & 0.080 & $0.760 * *$ & $0.662 * *$ & $0.640 * *$ \\
\hline EC & $0.730 * *$ & 0.114 & 0.095 & 0.292 & $0.409 *$ \\
\hline OM & 0.229 & $0.620 * *$ & -0.045 & -0.168 & -0.059 \\
\hline Avail. P & $0.593 * *$ & 0.276 & $0.652 * *$ & $0.684 * *$ & $0.689 * *$ \\
\hline Total N & 0.276 & $0.643^{* *}$ & 0.001 & -0.090 & -0.083 \\
\hline CEC & $0.447 *$ & $0.808 * *$ & $0.455^{*}$ & 0.284 & 0.382 \\
\hline Extr. $\mathrm{K}$ & $0.783^{* *}$ & 0.352 & 0.196 & 0.343 & $0.461 *$ \\
\hline Extr. Ca & $0.596 * *$ & 0.393 & $0.960 * *$ & $0.849 * *$ & $0.906^{* *}$ \\
\hline Sand (\%) & $-0.595^{* *}$ & $-0.432 *$ & $-0.538 * *$ & $-0.660 * *$ & $-0.648 * *$ \\
\hline Clay (\%) & $0.723 * *$ & $0.588 * *$ & $0.714^{* *}$ & $0.660 * *$ & $0.772 * *$ \\
\hline Silt (\%) & 0.215 & 0.085 & 0.121 & 0.400 & 0.253 \\
\hline
\end{tabular}

$*$, ** Correlation is significant at $p \leqslant 0.05$ or 0.01 , respectively.

direct reserve fraction to restock the available $\mathrm{Mg}$.

The largest component of soil Mg was the Mineral$\mathrm{Mg}$ in the inorganic soils (Fig. 1a and Fig. 1b). The bulk of soil $\mathrm{Mg}$ (around 90\%) is strongly fixed in the lattice structure of clay minerals and, as a result, inaccessible to sustain plant life [9]. High concentration of Avail-Mg was found in the fine textured and the organic soils, which is consistent with the existing information that fine textured soils hold large amounts (51-70\%) of soil Mg [10]. Additionally, higher levels of Avail-Mg in soils are found in clay soils. Clay particles are the source of negative charge to adsorb cations, such as $\mathrm{Mg}^{2+}$. Moreover, clay particles are important as a source of both primary $\mathrm{Mg}$ mineral (ferromagnesian clay mineral e.g. biotite and hornblende) and secondary $\mathrm{Mg}$ mineral (2:1 clay mineral e.g. vermiculite, montmorillonite, and saponite) $[28,29]$. Primary and secondary Mg mineral can release Mg and enhance soil $\mathrm{Mg}$ level. On the other hand, sand fraction normally lacks Mg-bearing minerals and exhibits a low negative charge; thus, a course texture soil has lower Avail-Mg and total-Mg than a fine texture soil. The positive relationships of Avail-Mg, Acid-Mg, and Mineral-Mg with clay particles, Extr. Ca, and Avail. P (Table 5) somehow affirmed coexistence of $\mathrm{Mg}, \mathrm{Ca}$, and $\mathrm{P}$ clay minerals in most Thai soils. Moreover, most $\mathrm{Mg}$ was found in young clay soils in Entisols (Tc soil series) which also demonstrated higher OM content. The Mollisols (Ln and Tk soil series) with a mollic epipedon were characterized by high base saturation. The Vertisols (Lb) with high soil pH and CEC (Table S2 and Table S3) equally illustrated high $\mathrm{Mg}$ content compared with the Ultisols, the main Thai soil series. These results demonstrate that soil $\mathrm{Mg}$ fertilization should be considered for the Thai Ultisols irrespective of their texture since they contain low available Mg. However, Thai Mollisols, Histosols, and a few young clay soils (at early stages of development like Entisols and Vertisols with higher soil $\mathrm{pH}$ and $\mathrm{CEC}$ ) contain enough $\mathrm{Mg}$ to sustain plants.

The OM-Mg was below $4 \%$ in mineral soils, and $43 \%$ of Thai soils have very low soil OM and CEC [30].
Moreover, the weak relationship between $\mathrm{Mg}$ fractions and CEC (Table 5) indicated low CEC in Thai soils, resulting in a low capacity to form complexes with $\mathrm{Mg}$. These results are reminiscent to previous reports in which OM-Mg contributes a diminutive fraction $(<5 \%)$ in total $\mathrm{Mg}$ fractionation in the soil [18]. However, in this study, the OM-Mg was elevated in the organic soils (14.68\%), perhaps, as a direct gain from the increased OM $(440 \mathrm{~g} / \mathrm{kg})$ within the soils (Table 2). $\mathrm{OM}$ is a source of plant nutrients, and the decomposition of litter is accelerated by elevated temperature and moisture resulting in increased $\mathrm{Mg}$ and other plant nutrient levels in soils [31]. Moreover, the significant positive correlations of $\mathrm{OM}-\mathrm{Mg}$ with total-N $\left(r=0.643^{* *}\right)$ and OM $\left(r=0.620^{* *}\right)$ (Table 5) illustrated the concurrent existence of both the $\mathrm{OM}-\mathrm{Mg}$ and the $\mathrm{N}$ in decomposed plant materials. $\mathrm{Mg}$ is estimated around $0.86-3.88 \mathrm{~g} / \mathrm{kg}$ in plant dry matters [10].

The acid soluble Mg fraction, Acid-Mg, is associated with carbonates, and the $\mathrm{Mg}$ content bound to carbonates is sensitive to $\mathrm{pH}$ changes and is extracted when soil $\mathrm{pH}$ is lowered [32]. The study results showed that an increase in soil $\mathrm{pH}$ to alkalinity was associated with higher content of Acid-Mg (Fig. 2) and strong positive correlations with soil $\mathrm{pH}$ of Acid $-\mathrm{Mg}$ $(r=0.760 * *)$ and Extr. Ca $(r=0.960 * *)$ (Table 5). The observed minor proportion of Acid-Mg in this study indicated the constrained presence of carbonates in the tropics, as carbonates are commonly found in dry semi-arid and arid areas with low rainfall where Calcisols are dominant [33]. In addition, the negative significant correlations between Mg chemical fractions and sand particles indicated that a higher content of sand in soil likely lowered the $\mathrm{Mg}$ reserves in soil [34].

The optimal level of available $\mathrm{Mg}$ range for Thai soils is $122-365 \mathrm{mg} / \mathrm{kg}$ [21] (Fig. 3). A high Avail$\mathrm{Mg}$ contents in the the fine textured and organic soils were noted. Besides, significant positive correlations between Avail-Mg and OM-Mg $\left(r=0.660^{* *}\right)$ (Table 4) and clay particles $\left(r=0.723^{* *}\right)$ (Table 5) were ob- 
served. This connection could be related to the clayhumus complex, the soil colloids with charges for cation adsorption and, therefore, holding a substantial amount of Avail-Mg. The available Mg fraction comprises a cationic $\mathrm{Mg}$ that is electrostatically adsorbed to negatively charged soil particles [33], and these results reveal that Thai medium and coarse textured soils with less clay content require addition of organic fertilizers to improve their colloidal soil component to hold more available $\mathrm{Mg}$.

Moderate Avail-Mg content was observed in coconut growing soils despite their coarse nature (Fig. 3b). This may be supported by the main environment type where Thai coconut is grown along the coastal regions where alkaline and saline soils with high contents of base cations prevail, and they also exhibit a high soil $\mathrm{pH}$ (Table 3). Low concentrations of Avail-Mg were observed in medium and coarse textured soils (Fig. 3a). These results agree with previous information that clay soils contain adequate exchangeable $\mathrm{Mg}$ for plant requirements [9]. However, some Ultisols clay soils, such as Hy, Kl, and Ro (Table S3) and sandy soils, showed low amounts of Avail-Mg and, therefore, required $\mathrm{Mg}$ replenishment.

In commercial crop cultivation soils, the Avail-Mg content was in descending order of rice $>$ coconut $>$ oil palm $>$ durian $>$ longkong $>$ rubber. These results show that only rice and coconut were grown in soils with sufficient $\mathrm{Mg}$ contents of high and moderate $\mathrm{Mg}$ concentrations, respectively. In contrast, oil palm, durian, longkong, and rubber are grown in $\mathrm{Mg}$ deficient soils (Fig. 3b). Similar results for the rank order of available $\mathrm{Mg}$ in Thai main commercial crop fields have been observed in previous studies [35]. Rice is grown in fine clay soils with high $\mathrm{Mg}$ and clay minerals, while coconut is grown in alkaline soils with higher $\mathrm{pH}$ and higher $\mathrm{Mg}$ quantities. The rest of the crops are grown in medium and coarse textured soils with low levels of Avail-Mg. Therefore, Thai soils with low available $\mathrm{Mg}$ below $122 \mathrm{mg} / \mathrm{kg}$ [21] should be restocked with $\mathrm{Mg}$ sources (like kieserite or dolomite) to increase soil $\mathrm{Mg}$. The application of these $\mathrm{Mg}$ sources does not only supply $\mathrm{Mg}$ but also promotes plant growth and production, similar to what has been demonstrated in rice [36].

Most of Mg within the inorganic soils is contained in soil minerals, while the available $\mathrm{Mg}$ is the dominant fraction in the organic soils. The available Mg exists in abundance within the soil colloids. As a result, the fine mineral soils and the organic soils hold enough $\mathrm{Mg}$ for plants. The carbonate and organic complexed $\mathrm{Mg}$ rose with soil $\mathrm{pH}$ and $\mathrm{OM}$ content, respectively. $\mathrm{Mg}$ fertilization should be considered for rubber, durian, oil palm, and longkong that are cultivated predominantly in medium and coarse textured soils with low available $\mathrm{Mg}$. The scale of various $\mathrm{Mg}$ forms to replenish available $\mathrm{Mg}$ is not clearly known; therefore, future assessment of the trend is essential for proper estimates of available $\mathrm{Mg}$.

\section{Appendix A. Supplementary data}

Supplementary data associated with this article can be found at http://dx.doi.org/10.2306/scienceasia1513-1874. 2022.028 .

Acknowledgements: This research was financially supported by the Prince of Songkla University, Graduate School, Hat Yai, Songkhla, Thailand.

\section{REFERENCES}

1. Hart RD, Wiriyakitnateekul W, Gilkes RJ (2003) Properties of soil kaolins from Thailand. Clay Miner 38, 71-94.

2. Meterological Department (2021) Climate Statistics. Available at: tmd.go.th/index.php.

3. Kheoruenromne A, Vijarnsorn P (2003) Soil Taxonomy key of Thailand Soils, Department of Soil Science, Kasetsart University, Bangkok, Thailand.

4. Funakawa S, Tanaka S, Kaewkhongkha T, Hattori T, Yonebayashi K (1997) Physicochemical properties of the soils associated with shifting cultivation in Northern Thailand with special reference to factors determining soil fertility. Soil Sci Plant Nutr 43, 665-679.

5. Yoothong K, Moncharoen L, Vijarson P, Eswaran H (1996) Clay mineralogy of Thai soils. Appl Clay Sci 11, 357-371.

6. Nganchamung T, Robson M (2017) Chemical fertilizer use and acute health effects among chili farmers in Ubon Ratchathani Province, Thailand. $J$ Health Res 31, 427-435.

7. Juntaraniyom T (2019) Farmer Manual for Efficiency of Oil Palm Production, Faculty of Natural Resources, Prince of Songklah University, Oil Palm Research and Development Center, Songkla, Thailand. [in Thai]

8. Kungpisdan N, Rattanchoat M, Permkrasin P, Kiwrum T, Chunamporn L, Thongphu A (2013) Development of Technology on Nutrition Management of Rubber, Department of Agriculture, Rubber Institute, Bangkok, Thailand. [in Thai]

9. Senbayram M, Gransee A, Wahle V, Thiel H (2015) Role of magnesium fertilisers in agriculture: plant-soil continuum. Crop Pasture Sci 66, 1219-1229.

10. Troeh FR, Thompson LM (2005) Soils and Soil Fertility, 6th edn, Blackwell Publishing, Replica Press, India.

11. Poonpakdee C, Tzeng JH, Weng CH, Lin YT (2018) Assessment of potassium speciation in the soil using traditional and modified sequential extraction processes. J Soils Sediments 18, 610-623.

12. Roberts D, Nachtegaal M, Sparks DL (2005) Speciation of metals in soils. In: Tabatabai M, Sparks D (eds), Chemical Processes in Soils, Soil Science Society of America, USA, pp 619-654.

13. Jones JB (2001) Laboratory Guide for Conducting Soil Tests and Plant Analysis, CRC Press, Florida, USA.

14. Tessier A, Campbell PGC, Bisson M (1979) Sequential extraction procedure for the speciation of particulate trace metals. Anal Chem 51, 844-851.

15. Hass A, Fine P (2010) Sequential selective extraction procedures for the study of heavy metals in soils, sediments, and waste materials-a critical review. Crit Rev Env Sci Tec 40, 365-399. 
16. Wang CY, Zhang Y, Li HL, Morrison RJ (2013) Sequential extraction procedures for the determination of phosphorus forms in sediment. Limnology 14, 147-157.

17. He J, Liu GL, Zhu DW, Cai JB, Zhou WB, Guo WW (2015) Sequential extraction of calcium in lake sediments for investigating the cycle of phosphorus in water environment. Int J Environ Sci Te 12, 1123-1136.

18. Osemwota IO, Omueti J, Ogboghodo AI (2009) Distribution of magnesium forms in surface soils of Central Southern Nigeria. S Afr J Soil Sci Plant Nutr 26, 59-63.

19. Mokwunye AU, Melsted SW (1972) Magnesium forms in selected Temperate and Tropical Soils. Soil Sci Soc Am J 36, 762-764.

20. Gee GW, Bauder JW (1986) Particle-size analysis. In: Klute A (ed) Physical and Minerological Methods: Methods of Soil Analysis Part 1, American Society of Agronomy, USA, pp 383-409.

21. Land Development Department (2003) Manual Analysis of Soil, Water, Fertilizer, Plant, Soil Amendment, and Analysis of Production Quarantine, Office of Science for land development, Bangkok, Thailand.

22. Mongia AD, Bandyopadhyay AK (1994) Soils of the Tropics, Vikas Publishing House PVT LTD, Dehli, India.

23. Siskawardani DD, Onthong J, Khawmee K, Poonpakdee C (2016) Manganese status in upland and lowland rubber-growing soils in Songkhla Province, Southern Thailand, Agri Nat Res 50, 321-325.

24. Soil Survey Staff (2014) Keys to Soil Taxonomy, 12th edn, USDA-Natural Resources Conservation Service, Washington DC, USA.

25. Land Development Department (2003) Charaterization of Established Soil Series in the Central Plain of Thailand, Land Development Department, Bangkok, Thailand.

26. Huang PM, Patel MC, Santagata, Bobet A (2009) Classification of Organic Soils, Publication FHWA/IN/JTRP2008/02. Joint Transportation Research Program, Indiana Department of Transportation and Purdue Univer- sity, West Lafayette, Indiana, USA.

27. McCarthy JF, Zachara JM (1989) Sub-surface transport of contaminants. Environ Sci Technol 23, 496-502.

28. Pozo M, Calvo JP (2018) An overview of authigenic magnesian Clays. Minerals 8, ID 520.

29. Mengel K, Kirkby EA, Kosegarten H, Appel T (2001) Magnesium. In: Mengel K, Kirkby EA, Kosegarten H, Appel T (eds) Principles of Plant Nutrition, Springer, Dordrecht, pp 541-552.

30. Kanjanakul N, Putuntarat S, Huntakul K (2000) Fertility Status of Soils in Thailand, Land Development Department, Bangkok, Thailand.

31. Li T, Lang S, Li L, Zhang S, Pu Y, Wang G, Xu X, Li $Y$, et al (2021) Potassium availability in tea plantations of different ages grown on Alfisols: Content, dynamics, release, and composition of potassium-bearing minerals. J Soil Sci Plant Nutr 21, 1252-1262.

32. Filgueiras AV, Lavilla I, Bendicho C (2002) Chemical sequential extraction for metal partitioning in environmental solid samples. $J$ Environ Monitor 4, 823-857.

33. Brady NC, Weil RR (2017) The Nature and Properties of Soils, 15th edn, Pearson Education Inc, Columbus, USA.

34. Zhang M, Riaz M, Liu B, Xia H, El-desouki Z, Jiang C (2020) Two-year study of biochar: achieving excellent capability of potassium supply via alter clay mineral composition and potassium-dissolving bacteria activity. Sci Total Environ 717, ID 137286.

35. Kitprasong P, Khawmee K, Poonpakdee C, Onthong J (2020) Soil magnesium: Status and ratios on potassium and calcium in economic crop planted soils of Southern Thailand. Thai Sci Technol J 29, 482-497. [in Thai]

36. Ahmed N, Khalil A, Gulshan AB, Bashir S, Saleem M, Hussain R, Ali MA, Iqbal J, et al (2020) The efficiency of magnesium $(\mathrm{Mg})$ on rice growth, biomass partitioning and chlorophyll contents in alkaline soil condition. Pure Appl Bio 10, 325-333. 


\section{Appendix A. Supplementary data}

Table S1 Soil texture of inorganic and organic Thai soils taxonomy classification.

\begin{tabular}{|c|c|c|c|c|c|c|c|c|}
\hline $\begin{array}{l}\text { Soil } \\
\text { type }\end{array}$ & $\begin{array}{l}\text { Textural } \\
\text { group }\end{array}$ & $\begin{array}{c}\text { Soil } \\
\text { series }\end{array}$ & $\begin{array}{c}\text { Sand } \\
(\%)\end{array}$ & $\begin{array}{l}\text { Clay } \\
(\%)\end{array}$ & $\begin{array}{l}\text { Silt } \\
(\%)\end{array}$ & $\begin{array}{c}\text { Textural } \\
\text { class }\end{array}$ & Soil taxonomy classification & $\begin{array}{l}\text { Soil } \\
\text { order }\end{array}$ \\
\hline \multirow{2}{*}{ Organic } & & $\mathrm{Nw}$ & _- & - & _ & _- & Dysic, isohyperthermic Typic Haplofibrists & Histols \\
\hline & & $\mathrm{Kd}$ & - & - & - & - & Loamy, mixed, superactive dysic,isohyperthermic Terric Sulfihemists & Histols \\
\hline \multirow{21}{*}{ Inorganic } & \multirow{11}{*}{ Fine } & Pc & 12 & 40 & 48 & SC & Very fine, kaolinitic, isohyperthermic Rhodic Kandiustox & Oxisols \\
\hline & & Ak & 16 & 68 & 16 & C & Very fine, kaolinitic, isohyperthermic Rhodic Kandiudoxs & Oxisols \\
\hline & & $\mathrm{Lb}$ & 7 & 68 & 25 & $\mathrm{C}$ & Very fine, kaolinitic, isohyperthermic Rhodic Kandiudoxs & Vertisols \\
\hline & & Hy & 76 & 12 & 12 & SL & Very fine, smectitic, isohyperthermic Typic Haplusterts & Ultisols \\
\hline & & Ro & 41 & 16 & 43 & $\mathrm{~L}$ & Clayey-skeletal,kaolinitic, isohyperthermic Typic Paleudults & Ultisols \\
\hline & & $\mathrm{Kl}$ & 20 & 24 & 56 & SiL & Very fine, kaolinitic, isohyperthermic Typic Plinthaquults & Ultisols \\
\hline & & $\mathrm{Bk}$ & 3 & 44 & 53 & SC & Very fine, smectitic, nonacid, isohyperthermic Vertic Endoaquepts & Vertisols \\
\hline & & $\mathrm{Mu}$ & 12 & 44 & 44 & SC & Fine, mixed, semiactive, acid, isohyperthermic Sulfic Endoaquepts & Vertisols \\
\hline & & $\mathrm{Tc}$ & 3 & 56 & 41 & SC & Fine, smectitic, nonacid, isohyperthermic Sodic Hydraquents & Entisols \\
\hline & & Ln & 6 & 52 & 42 & SC & Fine, smectitic, isohyperthermic Vertic Haplustolls & Mollisols \\
\hline & & Tk & 16 & 48 & 36 & $\mathrm{C}$ & Loamy-skeletal, carbonatic, isohyperthermic Entic Haplustolls & Mollisols \\
\hline & \multirow{5}{*}{ Medium } & $\mathrm{Pk}$ & 74 & 16 & 10 & SL & Fine, kaolinitic, isohyperthermic Typic Kandiudults & Ultisols \\
\hline & & $\mathrm{Fd}$ & 53 & 16 & 31 & SL & Fine-loamy, kaolinitic, isohyperthermic Rhodic Kandiudults & Ultisols \\
\hline & & Sw & 36 & 12 & 52 & SiL & Loamy-skeletal, mixed, semiactive, isohyperthermic Typic Paleudults & Ultisols \\
\hline & & $\mathrm{Vi}$ & 22 & 20 & 58 & SiL & Fine-loamy, mixed, semiactive, isohyperthermic Typic Plinthaquults & Ultisols \\
\hline & & $\mathrm{Ni}$ & 62 & 12 & 26 & SL & Fine, mixed, semiactive, isohyperthermic Typic Haplohumults & Ultisols \\
\hline & \multirow{5}{*}{ Coarse } & $\mathrm{Kh}$ & 76 & 8 & 16 & SL & Coarse-loamy, kaolinitic, isohyperthermic Typic Kandiudults & Ultisols \\
\hline & & Ko & 79 & 12 & 9 & SL & Fine-loamy, kaolinitic, isohyperthermic Typic Kandiaquults & Ultisols \\
\hline & & $\mathrm{Te}$ & 66 & 24 & 10 & SCL & Fine-loamy, kaolinitic, isohyperthermic Typic Kandiudults & Ultisols \\
\hline & & $\mathrm{Tg}$ & 83 & 8 & 9 & LS & Coarse-loamy, siliceous, subactive, isohyperthermic Typic Paleudults & Ultisols \\
\hline & & $\mathrm{Bc}$ & 91 & 4 & 5 & $\mathrm{~S}$ & Coated, isohyperthermic, Typic Quartzipsamments & Inceptisols \\
\hline
\end{tabular}

$\mathrm{C}=$ clay, $\mathrm{L}=$ loam, $\mathrm{S}=$ sand, $\mathrm{SCL}=$ sandy clay loam, $\mathrm{SL}=$ sandy loam, $\mathrm{SC}=$ silty clay, $\mathrm{SiL}=$ silty loam, and $\mathrm{LS}=$ loamy sand. Soil Classification based on Land Development Department [25].

Table S2 Physiochemical properties of Thai soil series.

\begin{tabular}{|c|c|c|c|c|c|c|c|c|c|c|}
\hline Soil type & $\begin{array}{l}\text { Texture } \\
\text { group }\end{array}$ & $\begin{array}{c}\text { Soil } \\
\text { series }\end{array}$ & $\mathrm{pH}$ & $\begin{array}{c}\text { EC } \\
\text { (ds/m) }\end{array}$ & $\begin{array}{c}\mathrm{OM} \\
(\mathrm{g} / \mathrm{kg})\end{array}$ & $\begin{array}{l}\text { Avai. P } \\
\text { (mg/kg) }\end{array}$ & $\begin{array}{l}\text { Total N } \\
(\mathrm{g} / \mathrm{kg})\end{array}$ & $\begin{array}{c}\mathrm{CEC} \\
\left(\mathrm{cmol}_{\mathrm{c}} / \mathrm{kg}\right)\end{array}$ & $\begin{array}{c}\text { Extr. K } \\
(\mathrm{mg} / \mathrm{kg})\end{array}$ & $\begin{array}{c}\text { Extr. Ca } \\
(\mathrm{mg} / \mathrm{kg})\end{array}$ \\
\hline \multirow{2}{*}{ Organic } & \multirow{2}{*}{-} & $\mathrm{Nw}$ & 4.01 & 0.12 & 432.00 & 5.63 & 8.01 & 85.39 & 19.85 & 602.39 \\
\hline & & $\mathrm{Kd}$ & 3.78 & 0.12 & 448.08 & 11.06 & 9.38 & 104.75 & 321.30 & 877.63 \\
\hline \multirow{21}{*}{ Inorganic } & \multirow{11}{*}{ Fine } & $\mathrm{Pc}$ & 5.71 & 0.07 & 17.88 & 9.37 & 1.13 & 10.53 & 83.78 & $1,707.26$ \\
\hline & & $\mathrm{Ak}$ & 7.50 & 0.14 & 12.28 & 6.70 & 1.01 & 10.77 & 32.05 & $4,013.02$ \\
\hline & & $\mathrm{Lb}$ & 7.26 & 0.14 & 12.60 & 18.20 & 0.54 & 54.25 & 30.47 & $13,149.53$ \\
\hline & & Hy & 5.61 & 0.02 & 13.99 & 5.25 & 0.51 & 1.40 & 15.68 & 12.45 \\
\hline & & Ro & 5.42 & 0.03 & 9.95 & 3.39 & 0.72 & 4.15 & 16.48 & 475.53 \\
\hline & & $\mathrm{Kl}$ & 4.88 & 0.06 & 13.03 & 7.41 & 0.80 & 4.06 & 30.48 & 376.01 \\
\hline & & Bk & 5.09 & 0.04 & 15.47 & 4.84 & 0.94 & 11.08 & 66.82 & 592.97 \\
\hline & & $\mathrm{Mu}$ & 3.66 & 2.51 & 56.92 & 4.67 & 1.78 & 18.63 & 133.99 & 243.86 \\
\hline & & $\mathrm{Tc}$ & 6.03 & 8.66 & 52.68 & 34.70 & 1.90 & 17.17 & 873.63 & $8,572.21$ \\
\hline & & Ln & 7.97 & 0.12 & 26.79 & 24.95 & 1.38 & 44.97 & 98.88 & $13,130.68$ \\
\hline & & Tk & 8.05 & 0.11 & 17.35 & 27.22 & 1.36 & 40.47 & 154.10 & $11,248.74$ \\
\hline & \multirow{5}{*}{ Medium } & $\mathrm{Pk}$ & 5.31 & 0.02 & 8.92 & 4.54 & 0.34 & 1.20 & 8.72 & 71.03 \\
\hline & & $\mathrm{Fd}$ & 5.03 & 0.03 & 8.51 & 8.86 & 0.50 & 1.58 & 7.21 & 36.61 \\
\hline & & Sw & 4.85 & 0.04 & 11.02 & 6.80 & 0.61 & 3.92 & 22.01 & 162.18 \\
\hline & & $\mathrm{Vi}$ & 4.71 & 0.03 & 10.02 & 6.96 & 0.78 & 4.43 & 18.38 & 92.51 \\
\hline & & $\mathrm{Ni}$ & 4.34 & 0.07 & 11.68 & 10.40 & 0.60 & 3.76 & 13.50 & 18.56 \\
\hline & \multirow{5}{*}{ Coarse } & $\mathrm{Kh}$ & 5.16 & 0.02 & 12.89 & 5.46 & 0.63 & 3.58 & 10.84 & 21.92 \\
\hline & & Ko & 5.33 & 0.02 & 6.01 & 8.26 & 0.37 & 1.46 & 4.89 & 112.98 \\
\hline & & $\mathrm{Te}$ & 5.13 & 0.02 & 13.37 & 5.30 & 0.71 & 4.36 & 10.64 & 24.64 \\
\hline & & $\mathrm{Tg}$ & 5.37 & 0.01 & 13.29 & 4.33 & 0.52 & 2.21 & 15.15 & 26.02 \\
\hline & & $\mathrm{BC}$ & 5.07 & 0.03 & 9.22 & 20.14 & 0.43 & 1.11 & 8.63 & 24.43 \\
\hline
\end{tabular}


Table S3 Concentrations of $\mathrm{Mg}$ fractions in Thai soil series.

\begin{tabular}{|c|c|c|c|c|c|c|c|c|c|}
\hline Soil type & $\begin{array}{l}\text { Textured } \\
\text { group }\end{array}$ & $\begin{array}{c}\text { Soil } \\
\text { sample }\end{array}$ & $\begin{array}{c}\text { Available } \\
\mathrm{Mg} \\
(\mathrm{mg} / \mathrm{kg})\end{array}$ & $\begin{array}{c}\text { Organic } \\
\text { complexed Mg } \\
(\mathrm{mg} / \mathrm{kg})\end{array}$ & $\begin{array}{c}\text { Acid soluble } \\
\text { Mg } \\
(\mathrm{mg} / \mathrm{kg})\end{array}$ & $\begin{array}{c}\text { Mineral } \\
\mathrm{Mg} \\
(\mathrm{mg} / \mathrm{kg})\end{array}$ & $\begin{array}{c}\text { Psuedo total } \\
\mathrm{Mg} \\
(\mathrm{mg} / \mathrm{kg})\end{array}$ & $\begin{array}{c}\text { Total } \\
\mathrm{Mg} \\
(\mathrm{mg} / \mathrm{kg})\end{array}$ & $\begin{array}{l}\text { Total } \mathrm{Mg} \\
\text { average } \\
(\mathrm{mg} / \mathrm{kg})\end{array}$ \\
\hline \multirow{2}{*}{ Organic } & \multirow{2}{*}{ - } & Nw & 259.77 & 45.87 & 8.73 & 60.25 & 337.49 & 314.95 & \multirow{2}{*}{606.10} \\
\hline & & $\mathrm{Kd}$ & 816.00 & 175.46 & 60.95 & 74.08 & 1011.98 & 897.25 & \\
\hline \multirow{22}{*}{ Inorganic } & \multirow{11}{*}{ Fine } & $\mathrm{Pc}$ & 146.46 & 25.20 & 14.55 & 186.94 & 373.15 & 369.99 & \multirow{22}{*}{707.83} \\
\hline & & $\mathrm{Ak}$ & 387.93 & 10.13 & 91.47 & 159.52 & 649.05 & 617.04 & \\
\hline & & $\mathrm{Lb}$ & 1403.44 & 145.94 & 395.66 & 616.02 & 2561.06 & 2974.32 & \\
\hline & & Hy & 38.25 & 4.56 & 9.21 & 81.92 & 133.94 & 124.38 & \\
\hline & & Ro & 123.75 & 10.79 & 13.87 & 274.27 & 422.68 & 453.20 & \\
\hline & & $\mathrm{Kl}$ & 66.92 & 18.98 & 10.26 & 244.07 & 340.23 & 333.75 & \\
\hline & & $\mathrm{Bk}$ & 576.35 & 11.25 & 43.12 & 420.13 & 1050.85 & 986.42 & \\
\hline & & $\mathrm{Mu}$ & 499.67 & 9.54 & 27.47 & 733.35 & 1270.04 & 1290.60 & \\
\hline & & Tc & 1856.04 & 50.13 & 112.02 & 716.73 & 2734.92 & 2667.45 & \\
\hline & & Ln & 328.40 & 25.18 & 355.08 & 1438.23 & 2146.90 & 2318.83 & \\
\hline & & Tk & 200.73 & 14.44 & 237.27 & 1087.74 & 1540.18 & 1763.44 & \\
\hline & \multirow{6}{*}{ Medium } & $\mathrm{Pk}$ & 15.53 & 3.36 & 8.35 & 102.77 & 130.02 & 116.63 & \\
\hline & & $\mathrm{Fd}$ & 20.96 & 3.62 & 4.84 & 59.79 & 89.22 & 79.78 & \\
\hline & & Ntn & 33.07 & 6.61 & 6.30 & 173.35 & 219.33 & 194.98 & \\
\hline & & Sw & 52.23 & 7.55 & 7.00 & 143.12 & 209.90 & 213.10 & \\
\hline & & $\mathrm{Vi}$ & 21.71 & 5.11 & 7.06 & 183.84 & 217.72 & 199.07 & \\
\hline & & $\mathrm{Ni}$ & 15.62 & 4.99 & 4.99 & 161.06 & 186.65 & 173.39 & \\
\hline & \multirow{5}{*}{ Course } & $\mathrm{Kh}$ & 14.82 & 5.69 & 5.69 & 90.62 & 116.82 & 102.65 & \\
\hline & & Кo & 24.89 & 5.84 & 5.84 & 86.64 & 123.20 & 109.49 & \\
\hline & & $\mathrm{Te}$ & 18.38 & 6.54 & 6.54 & 136.78 & 168.23 & 176.28 & \\
\hline & & $\mathrm{Tg}$ & 27.17 & 7.32 & 7.32 & 133.56 & 175.35 & 193.71 & \\
\hline & & $\mathrm{Bc}$ & 19.74 & 5.70 & 5.70 & 95.35 & 126.48 & 113.72 & \\
\hline
\end{tabular}

